Article

\title{
Sustainability Indicators for the Use of Resources-The Exergy Approach
}

\section{Christopher J. Koroneos ${ }^{1, *}$, Evanthia A. Nanaki ${ }^{2}$ and George A. Xydis ${ }^{3}$}

1 Unit of Environmental Science and Technology, Department of Chemical Engineering, National Technical University of Athens, 9 Heroon Polytechneiou Street, Zografou Campus, 15773 Athens, Greece

2 University of Western Macedonia, Department of Mechanical Engineering, Bakola and Sialvera, 50100 Kozani, Greece; E-Mail: evananaki@gmail.com

3 Technical University of Denmark, Department of Electrical Engineering, Frederiksborgvej 399, P.O. Box 49, Building 776, 4000 Roskilde, Denmark; E-Mail: gexy@risoe.dtu.dk

* Author to whom correspondence should be addressed; E-Mail: koroneos@chemeng.ntua.gr; Tel.: +30-210-772-3085; Fax: +30-210-772-3285.

Received: 17 July 2012; in revised form: 25 July 2012 / Accepted: 2 August 2012 /

Published: 20 August 2012

\begin{abstract}
Global carbon dioxide (CO2) emissions reached an all-time high in 2010, rising $45 \%$ in the past 20 years. The rise of peoples' concerns regarding environmental problems such as global warming and waste management problem has led to a movement to convert the current mass-production, mass-consumption, and mass-disposal type economic society into a sustainable society. The Rio Conference on Environment and Development in 1992, and other similar environmental milestone activities and happenings, documented the need for better and more detailed knowledge and information about environmental conditions, trends, and impacts. New thinking and research with regard to indicator frameworks, methodologies, and actual indicators are also needed. The value of the overall indicators depends on the production procedure of each material, and indicates their environmental impact. The use of "exergy indicators" based on the exergy content of materials and the use of the second law of thermodynamics in this work presents the relationship between exergy content and environmental impact.
\end{abstract}

Keywords: sustainability; exergy indicators; environmental impact 


\section{Introduction}

In 2010, it was noted that the total global $\mathrm{CO}_{2}$ emissions had increased by $30 \%$ since 2000 to a total of 33.0 billion tonnes and by $45 \%$ since 1990, the base year of the Kyoto Protocol [1]. In 1990, global emissions were 22.7 billion tonnes, an increase of $45 \%$ on the 1970 level of 15.5 billion tonnes. The growth rate of $45 \%$ of global $\mathrm{CO}_{2}$ emissions in the 20 years since 1990 had not changed compared to the 20 years prior to 1990 . However, there has been a geographical shift in the importance of the manufacturing sector as it becomes increasingly replaced by the less fuel-intensive service sector in industrialised countries. In 1990 the industrialised countries with a mitigation target for total greenhouse gas (GHG) emissions under the Kyoto protocol (including the USA that did not ratify the protocol) had a share in global $\mathrm{CO}_{2}$ emissions of $68 \%$ versus $29 \%$ for developing countries. The large regional variation in emission growth trends in 2010 were apportioned as follows: $54 \%$ for developing countries; $43 \%$ for mature industrialised countries; andthe remaining 3\% is accounted for by international air and sea transport.

As far as the EU is concerned, according to the Environmental Energy Agency (EEA) [2,3] GHG emissions, between 1990 and 2008, decreased by around 10.7\% in the EU-27 and by 5.5\% in the EU-15. GHG emissions in the EU-27 stands for $12 \%$ of global GHG emissions, excluding net $\mathrm{CO}_{2}$ removals from land use, land-use change and forestry (LULUCF). In case global emissions from deforestation are taken into account, the share rises to $11 \%$. Emission intensities declined in all EU-27 Member States between 1990 and 2007, with an average decline of 37\% for the EU-27 and 33\% in the EU-15. The five EU-15 Member States emitting the most greenhouse gases are, in decreasing order: Germany, the United Kingdom, Italy, France and Spain. In the EU-12, Poland emits the most GHG. The majority of GHG is emitted by the production of electricity and heat, road transportation, fossil fuel combustion in households and in manufacturing industries, agriculture and the iron and steel industry. Carbon dioxide $\left(\mathrm{CO}_{2}\right)$ emissions account for $83 \%$ of total $\mathrm{GHG}$ emissions, while methane $\left(\mathrm{CH}_{4}\right)$ and nitrous oxide $\left(\mathrm{N}_{2} \mathrm{O}\right)$ each represent $8 \%$ and $7 \%$ respectively of total emissions.

Between 1990 and 2007, EU-15 GHG emissions decreased by 4.3\%. The increase was noticed in the sectors of energy supply $(+1 \%)$ and transport $(+24 \%)$. In all other sectors, greenhouse gas emissions decreased between 1990 and 2007 with the highest decrease in relative terms achieved in the waste sector (-39\%). Compared to 2009 , the estimated 2010 GHG emissions increased by $2.3 \%$ in the EU-15 and by $2.4 \%$ in the EU-27. This implies that EU-15 greenhouse gas emissions were approximately $10.6 \%$ below the 1990 level in 2010 or $10.7 \%$ below the base year level [4].

Especially in residential and commercial sectors, the most energy consumption takes place in buildings. This includes energy used for controlling temperatures in buildings and for the buildings themselves, but also energy used for appliances, lighting and other installed equipment. According to the International Energy Agency (IEA) the total final energy used globally accounts for 7209 Mtoe. The residential and commercial sectors account for respectively 1951 Mtoe and 638 Mtoe, which is almost $40 \%$ of the final energy use in the world. The major part of this consumption is in buildings [5].

In this context, the development of a set of indicators that can denote the use of natural resources, and provide reliable information to policy makers of potential environmental problems arising from human activities in the building sector, is of great significance. The application of exergy analyses in the building sector and the development of exergetic indicators allows the possibility of increasing the 
total energy performance and the sustainability of the urban environment. The exergy analysis can also help in the development and choice of new technologies aimed at lower exergy use in the building environment and the quantification of energy savings.

\section{The Exergy Approach}

Exergy is a measure of quality of energy and it can be consumed or destroyed through the operation of any physical or mechanical system. Exergy can be described as the maximum work that can be produced from a given form of energy when it approaches thermodynamic balance with the environmental space.

In recent decades, there has been increasing interest in the use of the exergy concept. The energy utilization of a country can be assessed using exergy analyses to gain knowledge of its energy use efficiency. A large body of literature concerning the application of exergy analyses to countries energy systems has been carried out. It includes inter alia studies concerning the application of exergy analyses in the following countries: USA [6], Canada [7-9], Japan, Finland and Sweden [10,11], Turkey [12,13], UK [14] and Norway [15]. Also, as can be seen in the literature, there are a number of studies on exergy and energy analysis/utilization of sectors such as the industrial, transportation, public and private, agricultural, utility and residential sectors in Saudi Arabia [16-21]; the transport sector in China [22]; the transport sector in Greece [23]; Turkish residential-commercial sector [24,25], the utility, commercial and residential sectors in Malaysia [26,27]; exergy analysis of energy use in Greece [28]; as well as a modeling of sectoral energy and exergy utilization [29].

The development of exergetic indicators constitutes a useful tool that can give insight into e.g., the:

- extent to which the quality levels of energy supply (e.g., high-temperature combustion) and demand (e.g., low-temperature heat) are matched

- location and magnitude of energy degradation spots, resulting from e.g., heat transfer (temperature drop) or energy conversion (e.g., electricity or solar radiation into low-grade heat)

- environmental impact of producing, reusing and recycling building materials

- limitations (e.g., maximum thermodynamic efficiencies) and breakthrough needs (e.g., technology substitution) of complex systems

In addition exergy analysis can be applied as a decision making tool with the general goal of improving process efficiency as measured by work or work potential, or by identifying areas of exergy destruction or entropy production [30].

\section{Exergetic Sustainable Indicators}

Indicators are tools that provide necessary information and a useful benchmark for annotation and comparison of similar systems. The use of indicators can provide knowledge of any system and the mapping of complex issues, such as environmental issues, in order to estimate the progress of an impending development, as well as the overall situation and the "trends" of the given system. The building environment is a complicated system and thus, for its management and rational use of resources, the environmental indicators are a necessity. The environmental indicators simplify, 
quantify and connect the "'trends" of the data that are collected. They are a very important tool because:

- They provide a measure for assessing whether the goals planned have been achieved.

- They are very useful in making the general public comprehend the achievements that have taken place in the area of environmental protection.

- They help the public and governments focus on certain key-issues, affecting the relevant industries.

- They highlight the significance of the correlation between environmental problems and social and economic activities.

- They create a framework to collect data for environmental reports and studies.

The data required to support the functionality of the abovementioned indicators should be: readily available or made available at a reasonable cost/benefit ratio; adequately documented and of proven quality; updated at regular intervals in accordance with reliable procedures. The exergy concept fulfills most of these criteria [31].

The objectives set for the building under study are:

- The building should be able to cover the exergetic needs using several different energy sources at the appropriate rate.

- The most scarce exergetic resources, such as mineral and petrochemical fuels, should be stored and used only in special cases, such as when there is an urgent need. Use of renewable energy as much as possible.

- Increase the efficiency of the building's life cycle; for example, using materials with low exergy and reusability.

- $\quad$ Prioritize air quality in order to protect human health and the environment.

In order to evaluate the completion of the abovementioned objectives, the use of the following energetic indicators is necessary:

- Percentage of exergy which stems from renewable energy sources.

- Percentage of electric exergy which stems from renewable energy sources.

- Percentage of the building needs that can be met by networks of low temperature heat.

The exergy performance indicators that can be developed for the system under study are:

- Overall exergy consumption [E]

- Overall exergy consumption per unit of surface $\left[\mathrm{E}_{\mathrm{a}}=\mathrm{E} / \mathrm{A}\right]$

- Overall exergy consumption per dweller $\left[\mathrm{E}_{\mathrm{p}}=\mathrm{E} / \mathrm{p}\right]$

- Exergy consumption for heating $\left[\mathrm{E}_{\mathrm{h}}\right]$

- Exergy consumption for heating per unit of surface $\left[\mathrm{E}_{\mathrm{ha}}=\mathrm{E}_{\mathrm{h}} / \mathrm{A}_{\mathrm{h}}\right]$

- Exergy consumption for heating per dweller $\left[\mathrm{E}_{\mathrm{hp}}=\mathrm{E}_{\mathrm{h}} / \mathrm{p}\right]$

- Exergy consumption for heating per degree days $\left[\mathrm{E}_{\mathrm{hd}}=\mathrm{E}_{\mathrm{h}} / \mathrm{d}\right]$

- Exergy consumption for heating per degree days and surface $\left[\mathrm{E}_{\mathrm{hda}}=\mathrm{E}_{\mathrm{h}} /(\mathrm{dxA})\right]$

- Exergy consumption for lighting and domestic devices per dweller $\left[\mathrm{E}_{\mathrm{lp}}=\mathrm{E}_{1} / \mathrm{p}\right]$

- Exergy consumption for warm water (domestic use) per dweller $\left[\mathrm{E}_{\mathrm{wp}}=\mathrm{E}_{\mathrm{w}} / \mathrm{p}\right]$ 


\subsection{Exergy Consumption Indicators}

During the life cycle of a building, a great part of exergy destruction takes place during the production phase of building materials and in the construction phase. The exergetic consumption for producing one unit of material can be estimated using the following equation:

$$
\mathrm{E} p u=M c * e c+\sum \frac{L a, i+L t, i}{M p, i}=M c * e c+\frac{E i+E p, i-1-E p, i}{M p, i}
$$

where: $\mathbf{E}_{\mathbf{p u}}\left(\mathrm{pu}=\right.$ Product unit), $M_{c} * e_{c}$ is the overall chemical exergy contained in the raw materials, $L_{a, i}$ and $L_{t, i}$ are the exergetic loss of emissions and loss of the process i, $M_{p, i}$ the mass flow that is generated during the process $\mathrm{i}, E_{i}$ the exergy fed into the system during the process $\mathrm{i}, E_{p, i-1}$ the exergy fed into the system during the process $\mathrm{i}$ and derived from the $\mathrm{i}-1, E_{i}$ the exergy of the process $i-1$ that was carried out in the $i$. Summing all exergetic consumptions of all treatment processes, the total exergy that is required to produce one unit of a product-material and therefore the embodied exergy is obtained.

The indicators of Total Consumption Exergy (CExC = Cumulative Exergy Consumption) and the Performance of Material (\%), focus on the interaction between the production chain and the environment. Attention should be given to the necessary resources that have to be extracted from the ecosystem and the environmental impact of the emissions. In conjuction with the process and the performance of production, three variables must ultimately be measured: the environmental impact to extract the energy source and the raw materials, technological performance points and environmental impacts of emissions. The total Exergy Consumption ( $\mathrm{CExC}=$ Cumulative Exergy Consumption) and the yields of production chains for a number of industrial products - many of which are essential building materials - are presented in Table 1.

Table 1. Embodied Exergy of material and their production efficiency

\begin{tabular}{lcc}
\hline Product & CExC (MJ/kg) & Performance (\%) \\
\hline Polystyrene & 91,9 & 45,7 \\
Electricity & 4,17 & 24 \\
Copper & 147,4 & 1,4 \\
Zinc & 198,9 & 2,6 \\
Aluminum & 250,2 & 13,2 \\
Methanol & 73,1 & 30,7 \\
Acetylene & 236 & 20,7 \\
Propane & 61,6 & 79,3 \\
Concrete & 1,7 & 0 \\
Paper & 59,9 & 27,5 \\
Glass & 21,1 & 0,8 \\
Polyethylene & 86 & 54,1 \\
\hline
\end{tabular}




\subsection{Eco-Efficiency Indicators}

The eco-efficiency indicator is defined as the price of the product divided by the environmental effect during its entire life cycle.

$$
\text { Eco }- \text { efficiency }=\frac{\text { Price of a Product }}{\text { Environmental Impact of a Product }}
$$

In this type of indicators there are no formal rules regarding the recognition, measurement and presentation of information on the environmental effects to a system, or when comparing two or more systems. In order, to avoid this problem, the following formulation can be used as a calculation index:

$$
\mathrm{e}=\frac{\mathrm{T}_{\mathrm{p}}}{\mathrm{C}_{\mathrm{p}}}
$$

where $\mathrm{C}_{\mathrm{p}}$ is the exergy of all natural and recycled resources that are consumed in all steps of the production process of the product, plus the exergy that is required for reduction of all flows of losses; and $T_{p}$ is the price of the product expressed in units of exergy (GJ). In order to convert the price of products to the price of exergy, the following formulation is suggested:

$$
\mathrm{e}_{\mathrm{c}}=\frac{\mathrm{V}_{\mathrm{p}} / \mathrm{P}_{\mathrm{a}}}{\mathrm{E}_{\mathrm{p}}}
$$

where $\mathrm{P}_{\mathrm{a}}$ is the average price for a GJ of energy, $\mathrm{V}_{\mathrm{p}}$ is the product price, and $\mathrm{E}_{\mathrm{p}}$ is the total exergy that is consumed in the production process and the exergy that is required to reduce production losses. The average price for a GJ of energy can be calculated from the average consumption of all energy sources and their cost for each GJ.

$$
\mathrm{P}_{\mathrm{a}}=\sum \mathrm{R}_{\mathrm{i}} * \mathrm{P}_{\mathrm{i}}
$$

where $\mathrm{R}_{\mathrm{i}}$ is the percentage of the total energy from a particular source $\mathrm{i}$, and $\mathrm{P}_{i}$ is the cost of a GJ for that source. The eco-efficiency indicator combines economic and environmental performance of producing and selling (i.e., value of product) a product. However, if a product has an eco-efficiency value in the range of zero to unity, it means that the product is unsustainable, since the exergy value spent for making the product is greater than exergy spent on the product as valued by society. The indicator $\mathbf{e}_{\mathbf{c}}$ is economic in nature and requires somewhat a stable built-in exergy of a particular product. In order therefore to reach the terms of the eco-efficiency indicator, including the possibility of efficient production of products with immediate effect in the reduction of embodied exergy, it is necessary to introduce an indicator that refers to the performance of consumption of exergy during manufacturing of the product.

$$
\mathrm{e}_{\mathrm{x}}=\frac{\mathrm{P}_{\mathrm{a}}}{\mathrm{E}_{\mathrm{p}}}
$$

The indicator of eco-efficiency represents the environmental and economical efficiency of manufacture and sale of a product. 


\section{The Case Study of an Office Building in Greece}

The exergetic and environmental efficiency of an office building built in Athens is investigated. The lifecycle of the building consists of three distinct phases: construction, use and withdrawal. The construction phase consists of the construction and transportation of all construction materials used and the construction of the building. The use phase includes all activities related to the use of the building and has a lifespan of 80 years. These activities include all the exergy consumed in the building including that consumed for heating, air conditioning and lighting. The demolition phase of the building includes the transportation of materials generated for recycling or landfill. The materials used for the construction of the office building are: concrete, steel, bricks, masonry mortar, insulation materials, aluminum, glass, marble, gypsum fiberboard, paint, PVC, epoxy resin, roof slabs, ceramic tiles, light weight concrete, metals, wood [32]. Table 2 presents the overall mass and the percentage of participation of each material used in the building.

Table 2. Overall material masses and percentage of participation [33].

\begin{tabular}{lcc}
\hline Material & Mass (kg) & Percentage \% \\
\hline Concrete & $5,080,270$ & 83.22 \\
Reinforced steel & 251,255 & 4.12 \\
Masonry mortar & 275,128 & 4.51 \\
Bricks & $229,654,30$ & 3.76 \\
Emulsion paint & 1458 & 0.02 \\
Gypsum fiberboard & 3713,43 & 0.06 \\
Roof slabs & 5772,53 & 0.09 \\
Ceramic tiles & $13,460,52$ & 0.22 \\
PVC sheets & 2754,41 & 0.05 \\
Aluminum & 5443,84 & 0.09 \\
Glass & $26,828,10$ & 0.44 \\
Marble & $172,964,30$ & 2.83 \\
PVC corns & 2763,77 & 0.05 \\
Light weight concrete & $24,178,70$ & 0.40 \\
Epoxy resin & 8831,70 & 0.14 \\
Sum & 6104,477 & 100.00 \\
\hline
\end{tabular}

The total exergy of all materials used in the building is shown in Table 3. It is evident that although the cement use has the largest weight, the dominant position in the quantity of exergy is steel.

Table 3. Total exergy of all materials.

\begin{tabular}{lc}
\hline Material & Built exergy $(\mathbf{G j})$ \\
\hline Concrete & $8.636,459$ \\
Reinforced steel & $11.808,985$ \\
Plaster & $2.476,152$ \\
Bricks & 620,06661 \\
Lactic paint & 4,8114 \\
\hline
\end{tabular}


Table 3. Cont.

\begin{tabular}{lc}
\hline Material & Built exergy $(\mathbf{G j})$ \\
\hline Plasterboard & 25,99401 \\
Slate & 63,49783 \\
Ceramic tiles & 43,073664 \\
Polyvinyl chloride sheets & 225,86162 \\
Aluminum & $1.355,51616$ \\
Glass & 566,07291 \\
Marble & $2.075,5716$ \\
Grains polyvinyl & 218,33783 \\
Concrete roof & 31,43231 \\
Epoxy glue & 803,6847 \\
TOTAL & 28.956 \\
\hline
\end{tabular}

The use period of the building includes the exergy consumption for heating, air conditioning and lighting. The life span of the building is set to be 80 years. The consumption of electricity and natural gas was based on the climatological conditions of Greece. The heating needs are covered by natural gas, while lighting and cooling by electricity. Taking into consideration the fact that the exergy percentages (coefficient of energy quality) for these two energy carriers are $98 \%$ and $100 \%$ respectively, the exergy consumptions were calculated (Figure 1).

Figure 1. Exergy consumption at use phase.

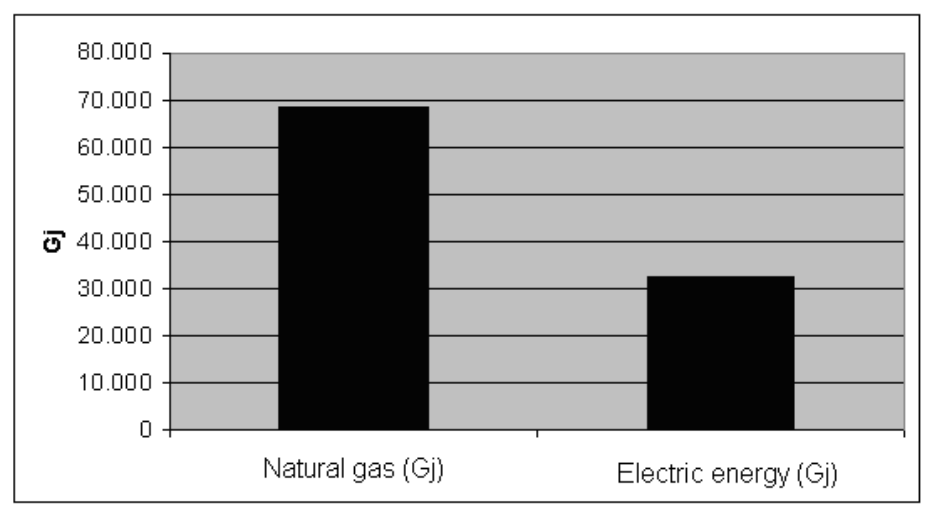

The eco-efficiency indicators for the material data used in the building under study are presented in Table 4 and Figure 2.

Table 4. Material data and Eco-efficiency.

\begin{tabular}{lccccc}
\hline Matrerial & CExC $\mathbf{( M j} / \mathbf{K g})$ & Pa (Euro/Gj) & Vp (Euro/Kg) & Fuel & Eco \\
\hline Concrete & 1,7 & 1,625 & 0,043 & lignite & 15,565 \\
Concrete & 1,7 & 0,51 & 0,043 & chopped tyres & 49,596 \\
Reinforced steel & 47 & 16 & 0,869 & natural gas & 1,155 \\
Reinforced steel & 47 & 27,8 & 0,869 & electricity & 0,665 \\
Masonry mortar & 9 & 7,53 & 0,271 & stone coal & 4 \\
Bricks & 2,7 & 21 & 0,12 & diesel & 2,11 \\
\hline
\end{tabular}


Table 4. Cont.

\begin{tabular}{lccccc}
\hline Matrerial & CExC (Mj/Kg) & Pa (Euro/Gj) & Vp (Euro/Kg) & Fuel & Eco \\
\hline Bricks & 2,7 & 27,8 & 0,12 & electricity & 1,598 \\
Bricks & 2,7 & 16 & 0,12 & natural gas & 2,78 \\
Emulsion paint & 3,3 & 16 & 4 & natural gas & 75,75 \\
Gypsum fiberboard & 7 & 7,53 & 0,522 & stone coal & 9,9 \\
Roof slabs & 11 & 27,8 & 2 & electricity & 6,54 \\
Ceramic tiles & 3,2 & 16 & 0,15 & natural gas & 2,929 \\
PVC sheets & 82 & 16 & 20 & natural gas & 15,243 \\
Aluminum & 249 & 27,8 & 4,33 & electricity & 0,625 \\
Glass & 21,1 & 14,99 & 0,55 & crude oil & 1,738 \\
Glass & 21,1 & 16 & 0,55 & natural gas & 1,629 \\
Glass & 21,1 & 27,8 & 0,55 & electricity & 0,937 \\
Marble & 12 & 21 & 4 & diesel & 15,87 \\
Light weight concrete & 1,3 & 1,625 & 0,043 & lignite & 20,35 \\
Epoxy resin & 91 & 16 & 9 & natural gas & 6,18 \\
\hline
\end{tabular}

Figure 2. Eco-Efficiency indicators.

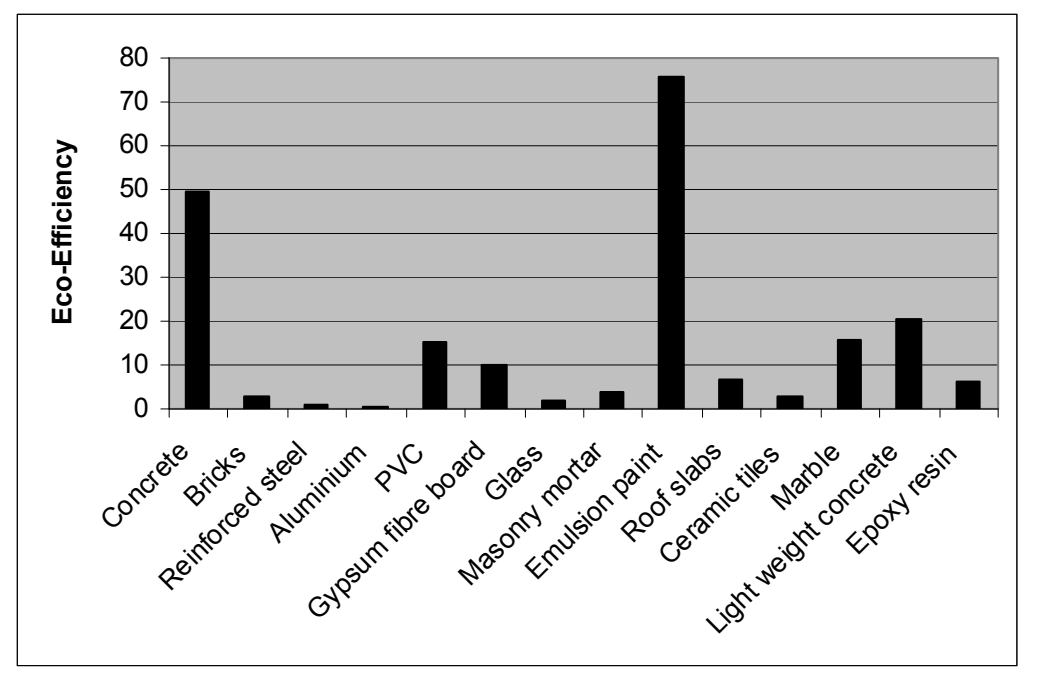

Using the indicators and the percentage of participation of each material, the overall Eco-efficiency indicator $\left(E_{k}\right)$ of the building is calculated. The overall indicator gives the environmental profile of the building and allows for comparison with other buildings. The overall indicator is calculated from the following formula:

$$
\sum_{\mathrm{i}=1}^{\mathrm{n}}\left(\mathrm{e}_{\mathrm{c}, \mathrm{i}}\right) \mathrm{x}\left(\mathrm{p}_{\mathrm{i}}\right)
$$

where $e_{c, i}$ is the eco-efficiency indicator of the material $i, p_{i}$ is the percentage of participation of the material I, and " $n$ " is the number of materials used in the building, which is 14 . In the building under study for the use phase, two indicators were calculated. The first is for materials with more sustainable production procedures (42.20) and the second for materials with less sustainable procedures used for production (13.81). 


\section{Conclusions}

The development of exergetic indicators plays a sigificant role in the investigation of the possibilities and advantages of a low carbon sustainable environment.

Based on data analyses of an office building in Greece, remarkable results outlining the exergetic profile of the building have been achieved. It was found that three quarters of the building's exergy consumption, during its 80 year life, stems from the use period (heating, cooling, lighting), while the remaining one quarter relates to its construction period (material extraction/process/transport). All this embodied exergy is proportional to the environmental impact of the material. The main material used in large quantities is concrete which has the least embodied exergy $(1.7 \mathrm{MJ} / \mathrm{Kg})$, while aluminum is the material with the highest embodied exergy (249 $\mathrm{MJ} / \mathrm{Kg}$ ) because of the very high energy demand during its production.

The exergy indicator is a good measure of sustainability for each material and its value is directly related to the processing fuel used. The values of this indicator are higher for concrete and emulsion paint and lower for aluminum, steel and bricks.

The value of the overall indicators depends on the production procedure of each material, and indicates their environmental impact. The use of "exergy indicators" based on the exergy content of materials and use of the second law of thermodynamics will lead to establishing the relationship between exergy content and the environmental impact. These indicators can help policy makers in selecting material and energy resources that will have a lower environmental impact in the long term.

\section{References}

1. JRC/PBL (European Commission, Joint Research Centre (JRC)/Netherlands Environmental Assessment Agency (PBL)). Long Term Trend in Global $\mathrm{CO}_{2}$ Emissions, 2011. Available online: http://pbl.nl/en (accessed on 21 September 2011).

2. Environmental Energy Agency (EEA). Greenhouse Gas Emission Trends and Projections in Europe 2009; EEA Report; Publications Office of the European Union: Copenhagen, Denmark, 2009.

3. Environmental Energy Agency (EEA). Approximate EU GHG Inventory: Early Estimates for 2010; Technical Report No. 11/2011; Publications Office of the European Union: Copenhagen, Denmark, 2011.

4. Environmental Energy Agency (EEA). Why Did Greenhouse Gas Emissions Fall in the EU in 2009?; Publications Office of the European Union: Copenhagen, Denmark, 2011. Available online: http://www.eea.europa.eu/publications/european-union-greenhousegasinventory-2011/why-did-greenhouse-gas emissions increased in the EU in 2010? (accessed on 22 March 2012).

5. Laustsen, J. Energy Efficiency Requirements in Building Codes: Energy Efficiency Policies for New Buildings; IEA Information Paper; International Energy Agency (IEA), Head of Communication and Information Office: Paris, France, 2008.

6. Reistad, G.M. Available energy conversion and utilization in the United States. J. Eng. Power 1975, 97, 429-434. 
7. Terkovics, P.J.; Rosen, M.A. Energy and Exergy Analysis of Canadian Energy Utilization Research Report; Ryerson Polytechnic University: Toronto, Canada, 1988.

8. Lemieux, M.A.; Rosen, M.A. Energy and Exergy Analysis of Energy Utilization in Ontario, Research Report; Ryerson Polytechnic University: Toronto, Canada, 1989.

9. Rosen, M.A. Evaluation of energy utilization efficiency in Canada using energy and exergy analyses. Energy Int. J. 1992, 17, 339-350.

10. Wall, G. Exergy conversion in the Japanese Society. Energy Int. J. 1990, 15, 435-444.

11. Wall, G. Exergy Conversions in the Finish, Japanese and Swedish Societies; Opuscula Exergy Papers; University College of Eskilstuna: Vasteras, Sweden, 1991; pp. 1-11.

12. Ozdogan, O.; Arikol, M. Energy and exergy analyses of selected Turkish Industries. Energy Int. J. 1995, 20, 73-80.

13. Rosen, M.A.; Dincer, I. Sectoral energy and exergy modeling of Turkey. ASME J. Energy Resour. Technol. Resour. Technol. 1997, 119, 200-204.

14. Hammond, G.P.; Stapleton, A.J. Exergy analysis of the United Kingdom Energy System. IMEchE J. Power Energy 2001, 215, 141-162.

15. Ertesvåg, I. Energy, exergy, and extended-Exergy analysis of the Norwegian society 2000. Energy 2005, 30, 649-675.

16. Dincer, I.; Hussain, M.M.; Al-Zaharnah, I. Energy and exergy use in the industrial sector of Saudi Arabia. Proc. I. MECH E. Part A J. Power Energy 2003, 217, 481-492.

17. Dincer, I.; Hussain, M.M.; Al-Zaharnah, I. Energy and exergy utilization in transportation sector of Saudi Arabia. Appl. Therm. Eng. 2004, 24, 525-538.

18. Dincer, I.; Hussain, M.M.; Al-Zaharnah, I. Energy and exergy use in public and private sector of Saudi Arabia. J. Energy Policy 2004, 32, 1615-1624.

19. Dincer, I.; Hussain, M.M.; Al-Zaharnah, I. Energy and exergy use in the utility sector of Saudi Arabia. Desalination 2004, 169, 245-255.

20. Dincer, I.; Hussain, M.M.; Al-Zaharnah, I. Energy and exergy use in residential sector of Saudi Arabia. Energy Sources 2004, 26, 1239-1252.

21. Dincer, I.; Hussain, M.M.; Al-Zaharnah, I. Energy and exergy utilization in agricultural sector of Saudi Arabia. Energy Policy 2005, 33, 1461-1467.

22. Ji, X.; Chen, G.Q. Exergy analysis of energy utilization in the transportation sector in China. J. Energy Policy 2005, 34, 1709-1719.

23. Koroneos, C.; Nanaki, E. Energy and exergy utilization assessment of the Greek transport sector. Resour. Conserv. Recycl. 2008, 52, 700-706.

24. Utlu, Z.; Hepbasli, A. A study on the evaluation of energy utilization efficiency in the Turkish residential-commercial sector using energy and exergy analyses. Energy Build. 2003, 35, $1145-1153$.

25. Utlu, Z.; Hepbasli, A. Analysis of energy and exergy use of the Turkish residential - Commercial sector. Build. Environ. 2005, 40, 641-655.

26. Saidur, R.; Masjuki, H.H.; Jamaluddin, M.Y. An application of energy and exergy analysis in residential sector of Malaysia. Energy Policy 2007, 35, 1050-1063.

27. Saidur, R.; Sattar, M.A.; Masjuki, H.H.; Abdessalam, H.; Shahruan, B.S. Energy and exergy analysis at the utility and commercial sectors of Malaysia. Energy Policy 2007, 35, 1956-1966. 
28. Hepbasli, A. A modeling of sectoral energy and exergy utilization. Energy Sources 2005, 27, 903-912.

29. Koroneos, C.; Nanaki, E.; Xydis, G. Exergy analysis of the energy use in Greece. Energy Policy 2011, 39, 2475-2481.

30. Gaudreau, K.; Fraser, R.A.; Murphy, S. The tenuous use of exergy as a measure of resource value or waste impact. Sustainability 2009, 1, 1444-1463. Available online: http://www.mdpi.com/ 2071-1050/1/4/1444 (accessed on 22 April 2012).

31. Gong, M.; Wall, G. On exergy and sustainable development-Part 2-Indicators and methods. Exergy Int. J. 2001, 1, 217-233.

32. SUSCON. Sustainable Construction in Public and Private Works through IPP Approach; LIFE05 ENV/GR/000235; European Commission: Brussels, Belgium, 2008.

33. Koltun, P.; Tharumarajah, A. An Exergy-Based Environmental Indicator for Manufacturing Systems. In Proceedings of the IEEE International Conference on Systems, Man and Cybernetics (ISIC), Highett, VIC, Australia, 7-10 October 2007.

(C) 2012 by the authors; licensee MDPI, Basel, Switzerland. This article is an open access article distributed under the terms and conditions of the Creative Commons Attribution license (http://creativecommons.org/licenses/by/3.0/). 